\title{
Effects of Levels of Growth Regulator and Application Periods in Maize Genotypes on the Agronomic Traits
}

\author{
Michelle N. Barcelos ${ }^{1}$, Reginaldo de Camargo ${ }^{2}$, Regina M. Q. Lana ${ }^{2}$, Uirá do Amaral ${ }^{3}$, Ronaldo da S. Viana ${ }^{4}$, \\ Thiago A. R. Nogueira ${ }^{5} \&$ Ana C. Alves ${ }^{6}$ \\ ${ }^{1}$ School of Agricultural and Veterinary Studies, São Paulo State University, Jaboticabal, SP, Brazil \\ ${ }^{2}$ Institute of Agrarian Sciences, Federal University of Uberlândia, Uberlândia, MG, Brazil \\ ${ }^{3}$ Federal Institute of Brasília, Planaltina, DF, Brazil \\ ${ }^{4}$ School of Agricultural and Technological Sciences, São Paulo State University, Dracena, SP, Brazil \\ ${ }^{5}$ School of Engineering, São Paulo State University, Ilha Solteira, SP, Brazil \\ ${ }^{6}$ Mato Grosso do Sul State University, Cassilândia, MS, Brazil \\ Correspondence: Michelle N. Barcelos, School of Agricultural and Veterinary Studies, São Paulo State \\ University, Jaboticabal campus, SP, Brazil. Tel: 55-34-3412-2869. E-mail: michelleuems@gmail.com
}

Received: July 3, $2019 \quad$ Accepted: July 27, $2019 \quad$ Online Published: September 30, 2019

doi:10.5539/jas.v11n16p151 URL: https://doi.org/10.5539/jas.v11n16p151

\begin{abstract}
The objective of this study was to evaluate the agronomic characteristics of corn hybrids short cycle on levels of plant regulator Stimulate ${ }^{\circledR}$ in two periods. The planting was done in field, in the experimental farm of the Mato Grosso do Sul State University. The experimental design was completely randomized, in a factorial scheme $(3 \times$ $2 \times 2)$, with four replicates. The treatments consisted of three levels $\left(0,250\right.$ and $500 \mathrm{~mL} \mathrm{ha}^{-1)}$ of the plant regulator, with two hybrids (30A37PW Morgan and P3646-HY) and two times of application (vegetative stage and reproductive stage). The following averages were evaluated: plant height, number of leaves, tassel weight, tang weight, tang length, leaf weight, number of spikes, stem weight, stem diameter, ear diameter and whole plant weight. The number of leaves, number of spikes and stalk diameter were higher to P3646-HY and the tassel weight was higher to Morgan 30A37PW. The application of growth regulator of the doses of 250 and $500 \mathrm{~mL}$ $\mathrm{ha}^{-1}$, divided in the vegetative and reproductive stages, caused a reduction in stem diameter and whole plant weight, and in the other parameters the application in single dose and in divided dose did not affect plant growth. The genotype P3646-HY obtained higher number of leaves, number of spikes and stem diameter than the genotype 30A37PW Morgan, but this presented higher tassel weight.
\end{abstract}

Keywords: Zea mays L., biostimulant, plant hormones, bulky production, behavior of varieties, sustainable agriculture

\section{Introduction}

Corn is an important product of human food and has a prominence in Brazilian agribusiness, ranking fourth in world exports and tenth in world imports (CONAB, 2019), responsible for productivity of 16616.4 mil ha in the harvest of 2017/18 (USDA, 2019). Research to improve the profitability of the crop by obtaining plants with desirable agronomic characteristics that respond to the technological innovations, are necessary to soften the reduction of corn production in the off season.

The technological level employed in agriculture can directly influence crop productivity. Therefore, the higher the technological level used in maize, the greater its yield, especially the use of biostimulants, since its use may be of great interest to the farmer to improve both the productivity and the quality of the corn (Tejada et al., 2018). In addition, some hybrids have lower production costs and better response to technological innovations (Lujan et al., 2015).

Plant regulators are natural or synthetic substances that, applied to plants, have a similar action as plant hormones, with the ability to promote, inhibit or modify physiological processes of plants. Those products act in the morgogenesis of plants by dividing and cell stretching, due to the presence of plant hormones as gibberellic acid, cytokinin and auxin (Taiz \& Zeiger, 2013), depending on factors such as crop farming and applied amount. 
The biostimulants are registered in the Ministry of Agriculture, Livestock and Supply, in the Regulator of Plant Growth class, of the Agrochemicals Legislation, and are not prohibited in organic agriculture, provided that follow the same mode of action of the regulators of natural or biological origin. Therefore, in Brasilian legislation "hormones and growth regulators: substances synthesized in a part of the organism, transported to other sites where they exercise behavioral control or regulate the growth of organisms" (Brazil, 2011).

Recent studies have shown positive results regarding the use of biostimulant, allowing a sustainable agricultural management, optimizing the use of area, without environmental risk. When applied biostimulant, in situations with isolated and combined stresses of type hypoxic, saline, nutritional, hypoxic plus nutritional and saline plus nutritional, in maize, were verified increments on root length, confirming greater tolerance to abiotic stress (Trevisan et al., 2019). This may be related to the stimulus of nitrogen metabolism and antioxidant systems in the plant (Ertani et al., 2013).

Different doses of biostimulant applied to corn seeds allowed a higher root biomass of $20 \%$ for plants with a half dose, a modest but significant effect of $12 \%$ on root biomass was recorded for plants grown in the presence of the complete dose, and the biomass of the aerial part remained unchanged in the three growing conditions (Trevisan et al., 2017).

The foliar application or seed treatment with synthetic hormones in maize, allowed an increase in the number of tillers, ears and grains per ear, the hectoliter weight and 1000 grains, grain yield in two stages, tillering and flowering (Santos et al., 2013).

The main objective of this research was to analyze the effects of different levels of Stimulate ${ }^{\circledR}$ on two maize genotypes in two times of application, considering the importance of improving the management of maize crops of between-harvest in the period of water deficiency and the need to produce food at this time of year.

\section{Method}

A field experiment was carried out in the experimental farm of the Mato Grosso do Sul State University, at

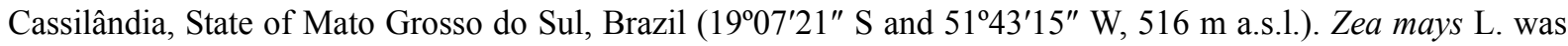
used as test plant and cropped in the annual harvest period in climatic conditions (Inmet, 2014) every twenty days, between the years of 2013 and 2014 (Figure 1).

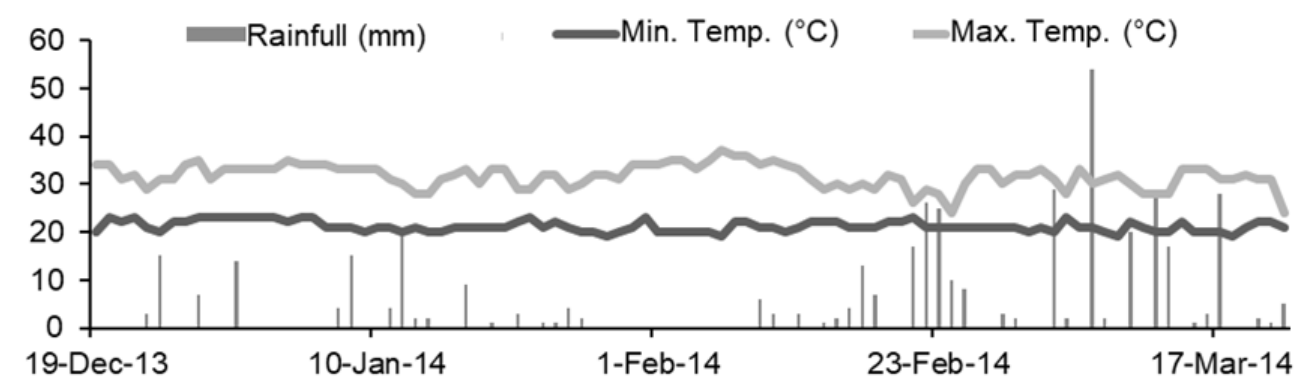

Figure 1. Meteorological data at the time of the experiment

The site soil is a Quartzipsamment (Entisol) (Soil Survey Staff, 2014) originally under vegetation of Cerrado, whose granulometric characteristics are: 835.81 and $84 \mathrm{~g} \mathrm{~kg}^{-1}$ of sand, silt and clay, respectively. Before of the experiment installation was performed soil sampling for the determination of the chemical characteristics, in the 0-0.20 m (Raij et al., 2001).

The planting was carried out on December 20 of 2013 with the use of mechanized planter, the corn cultivars 30A37PW Morgan and P3646-HY. Both hybrids have early cycle, recommended for planting in the between-harvest for green ear and silage production, being a product used in animal and human feeding.

The spacing was $90 \mathrm{~cm}$ between rows and 10 seeds per meter, and 4 rows per plot of $3 \times 3 \mathrm{~m}$. At the time of sowing, planting fertilization occurred applying the NPK formulation 04-20-20 at the dose of $950.62 \mathrm{~kg} \mathrm{ha}^{-1}$.

Plant thinning was performed 20 days after planting, using scissors to remove the plants, and the spacing of 10 $\mathrm{cm}$ between the plants of each row was left. On the following day nitrogen fertilization was done, with a dose of approximately $107 \mathrm{~kg} \mathrm{ha}^{-1}$ of nitrogen, weighed in analytical balance, divided and separated in plastic punches for the simultaneous application in each plot. 
Phytosanitary control of pests was carried out in 25 days after planting, by applying the insecticide Malathion ${ }^{\circledR}$ as recommended by the package leaflet, at the dose of $3 \mathrm{~mL} \mathrm{~L}^{-1}$ of water, applied by means of a $20 \mathrm{~L}$ costal pump in all maize plants, due to the presence of cartridge caterpillar and spittlebug. Weed control was performed by manual weeding in the internal area, and mechanized brushcutting at the ends of the experiment.

The growth regulator used was the Stimulat ${ }^{\circledR}$ of company Stolle, has the active ingredients $0.05 \mathrm{~g} \mathrm{~L}^{-1}$ of 4-indol-3-ylbutyric acid, $0.05 \mathrm{~g} \mathrm{~L}^{-1}$ of gibberellic acid and $0.09 \mathrm{~g} \mathrm{~L}^{-1}$ of kinetin, that is, this substance is in the group, such as auxin, gibberellin or cytokinin, whose main function is to stimulate plant growth in the formulation of soluble concentrate.

The experimental design was completely randomized, in a factorial scheme $(3 \times 2 \times 2)$, with four replicates. The treatments consisted of three levels $\left(0,250\right.$ and $\left.500 \mathrm{~mL} \mathrm{ha}^{-1}\right)$ of the Stimulate ${ }^{\circledR}$, with two hybrids $(30 \mathrm{~A} 37 \mathrm{PW}$ Morgan and P3646-HY) and two periods of application (vegetative and reproductive stages).

First application of the growth regulator occurred four weeks after emergence, when the plants have eight leaves developed. Second application was after one month of the first, at the phenological stage of tasseling. Both application, the Natur'l ${ }^{\circledR}$ oil adjuvant was added at the dosage of $0.5 \%$ volume of mineral oil per volume of water. The products were homogenized in a hand sprayer of one liter, being sprayed on the air part.

The following averages were evaluated: plant height, number of leaves, tassel weight, tang weight, tang length, leaf weight, number of spikes, stem weight, stem diameter, ear diameter and whole plant weight.

Evaluations by collecting four plants per plot in stage of pasty grain, to obtain the averages and these data were submitted to analysis of variance through the statistical program SisVar (Ferreira, 2011) and means where significant were grouped according to Tukey's test $(p<0.05)$. In the existence of interaction the unfolding was obtained, being studied only those that showed significant differences.

\section{Results and Discussion}

Between the levels 0,250 and $500 \mathrm{~mL} \mathrm{~h}^{-1}$ of Stimulate ${ }^{\circ}$ did not affect the variables plant height, number of leaves, tassel weight, tang weight and tang length (Table 1). Similarly to time of application, vegetative stage and reproductive stage (Table 1).

There was a significant effect between maize genotypes just the number of leaves and tassel weight (Table 1), because from P3646-HY the number of leaves was better and from 30A37PW Morgan the tassel weight was better, when the two hybrids were compared.

There was significant interaction for Stimulate ${ }^{\circledR} \times$ Time, and for Stimulate ${ }^{\circledR} \times$ Genotypes $\times$ Time (Table 1), demonstrating that the management of the biostimulant used may influence plant growth when applied at different times or in different genotypes.

The maize hybrid SG-6418 for silage, there was no interaction between fertilization level, row spacing and planting density, for plant height, nor for spike insertion height and number of dry leaves per plant in the application of biostimulant (Turco, 2011).

How in this work, the maize hybrid P3646-HY and 30A37PW Morgan, showed phenotypic differences in planting conditions, when it used levels of biostimulant and different times of application (Tables 1 and 2). However, for silage production, it can be verified that the whole plant weight was higher at any dose and time of application of the product to P3646-HY (Table 6).

Studying maize genotypes, the $30 \mathrm{~F} 53 \mathrm{YH}$ cultivar presented better results than the cultivar $30 \mathrm{~F} 53$ in the parameters number of spikes, plant height and stem diameter, with increment of these results when Stimulate ${ }^{\circledR}$ was used for both genotypes (Martins et al., 2016). 
Table 1. Mean for the Plant Height (PH) in cm, Number of Leaves (NL), Tassel Weight (TW) in g, Tang Weight (TAW) in $g$ and Tang Length (TL) in $\mathrm{cm}$ on levels of Stimulate ${ }^{\circledR}$, in two times vegetative stage (VS) and reproductive stage (RS) and genotypes (P3646-HY and 30A37PW Morgan) of maize.

\begin{tabular}{|c|c|c|c|c|c|}
\hline \multirow{2}{*}{ Treatments } & \multicolumn{5}{|c|}{ Parameters } \\
\hline & $\mathrm{PH}$ & NL & TW & TAW & $\mathrm{TL}$ \\
\hline \multicolumn{6}{|l|}{ Stimulate ${ }^{\circledR}(S)$} \\
\hline $0 \mathrm{~mL} \mathrm{~h}^{-1}$ & $1.30 \mathrm{a}$ & $11.37 \mathrm{a}$ & $3.95 \mathrm{a}$ & $200.17 \mathrm{a}$ & $23.92 \mathrm{a}$ \\
\hline $250 \mathrm{~mL} \mathrm{~h}^{-1}$ & $1.31 \mathrm{a}$ & $11.69 \mathrm{a}$ & $3.96 \mathrm{a}$ & $204.36 \mathrm{a}$ & $24.21 \mathrm{a}$ \\
\hline $500 \mathrm{~mL} \mathrm{ha}^{-1}$ & $1.32 \mathrm{a}$ & $11.69 \mathrm{a}$ & $3.72 \mathrm{a}$ & $200.31 \mathrm{a}$ & $24.24 \mathrm{a}$ \\
\hline \multicolumn{6}{|l|}{ Genotypes $(G)$} \\
\hline P3646-HY & $1.34 \mathrm{a}$ & $12.06 \mathrm{a}$ & $3.45 b$ & $204.14 \mathrm{a}$ & $24.50 \mathrm{a}$ \\
\hline 30A37PW Morgan & $1.28 \mathrm{a}$ & $11.19 \mathrm{~b}$ & $4.27 \mathrm{a}$ & $199.67 \mathrm{a}$ & $23.83 \mathrm{a}$ \\
\hline \multicolumn{6}{|l|}{ Times $(T)$} \\
\hline VS & $1.32 \mathrm{a}$ & $11.69 \mathrm{a}$ & $3.96 \mathrm{a}$ & $216.64 a$ & $24.75 \mathrm{a}$ \\
\hline $\mathrm{VS}+\mathrm{RS}$ & $1.31 \mathrm{a}$ & $11.69 \mathrm{a}$ & $3.72 \mathrm{a}$ & $188.04 \mathrm{a}$ & $23.70 \mathrm{a}$ \\
\hline \multicolumn{6}{|l|}{$F$-test } \\
\hline S & $0.12^{\mathrm{NS}}$ & $1.12^{\mathrm{NS}}$ & $0.40^{\mathrm{NS}}$ & $0.07^{\mathrm{NS}}$ & $0.08^{\mathrm{NS}}$ \\
\hline G & $3.79^{\mathrm{NS}}$ & $27.48^{*}$ & $10.76^{*}$ & $0.17^{\mathrm{NS}}$ & $1.26^{\mathrm{NS}}$ \\
\hline $\mathrm{T}$ & $0.10^{\mathrm{NS}}$ & $1.12^{\mathrm{NS}}$ & $0.42^{\mathrm{NS}}$ & $2.75^{\mathrm{NS}}$ & $1.36^{\mathrm{NS}}$ \\
\hline $\mathrm{S} \times \mathrm{G}$ & $1.30^{\mathrm{NS}}$ & $0.50^{\mathrm{NS}}$ & $1.47^{\mathrm{NS}}$ & $1.63^{\mathrm{NS}}$ & $0.82^{\mathrm{NS}}$ \\
\hline $\mathrm{S} \times \mathrm{T}$ & $0.12 *$ & $1.12 *$ & $0.40^{*}$ & $0.07 *$ & $0.08 *$ \\
\hline $\mathrm{G} \times \mathrm{T}$ & $0.20^{\mathrm{NS}}$ & $0.28^{\mathrm{NS}}$ & $0.67^{\mathrm{NS}}$ & $1.46^{\mathrm{NS}}$ & $0.62^{\mathrm{NS}}$ \\
\hline $\mathrm{S} \times \mathrm{G} \times \mathrm{T}$ & $0.12 *$ & $1.12 *$ & $0.40^{*}$ & $0.07 *$ & $0.08^{*}$ \\
\hline $\mathrm{CV}(\%)$ & 7.56 & 4.54 & 20.57 & 17.12 & 7.73 \\
\hline
\end{tabular}

Note. Means followed by same letters, uppercase in the column and lowercase in the line, are not significantly different by the Tukey's test at $p<0.05 . * *$ Significant at the level $p<0.01 .{ }^{*}$ Significant at the level $\mathrm{p}<0.05$. ns: not significant.

Between the levels 0,250 and $500 \mathrm{~mL} \mathrm{~h}^{-1}$ of Stimulate ${ }^{\circledR}$ did not affect the variables leaf weight, number of spikes, stem weight, stem diameter, ear diameter and whole plant weight (Table 2).

There was a significant effect between maize genotypes just to number of spikes and stem diameter (Table 2), because from P3646-HY the number of spikes and stem diameter was better, when the two hybrids were compared.

Times of application of Stimulate ${ }^{\circ}$, vegetative stage and reproductive stage, showed significant effect (Table 2), just to parameters stem diameter and whole plant weight, with higher values in single application in vegetative stage than divided in vegetative stage and reproductive stage.

There was significant interaction for Stimulate ${ }^{\circledR} \times$ Time, and for Stimulate ${ }^{\circledR} \times$ Genotypes $\times$ Time (Table 2), also demonstrating that the management of the biostimulant used may influence plant growth when applied at different times or in different genotypes.

The application of corn in the aerial part of biostimulant based on seaweed extract Egeria densa and Ascophyllum nodosum, with one or two applications, was not expressive in the increment of the plant height variable (Galindo et al., 2015).

The forms of application of the biostimulant, can also interfere in the utilization of these hormones by the crop, because when applied in seeds or early development, can promote increase in grain production, which enables plants to resist biotic, biological and nutritional stresses (Dourado-Neto et al., 2014).

The use of biostimulant in popcorn corn with four different levels $\left(0,5,10\right.$ and $20 \mathrm{~mL} \mathrm{~kg}^{-1}$ of seed) of the Stimulate ${ }^{\circledR}$ product showed a significant response to stem diameter, and no effect on leaf number and plant height (Oliveira et al., 2016).

Biostimulants do not cause significant effects on soy, maize and bean crops after seed treatment, possibly due to the influence of favorable climatic conditions during the growing season (Bontempo et al., 2016). 
Table 2. Mean for the Leaf Weight (LW) in g, Number of Spikes (NS), Stem Weight (SW) in cm, Stem Diameter (SD) in $\mathrm{cm}$, ear diameter (ED) in $\mathrm{cm}$ and Whole Plant Weight (WPW) in $\mathrm{g}$ on levels of Stimulate ${ }^{\circledR}$, in two times vegetative stage (VS) and reproductive stage (RS) and genotypes (P3646-HY and 30A37PW Morgan) of maize

\begin{tabular}{lllllll}
\hline \multirow{2}{*}{ Treatments } & \multicolumn{5}{c}{ Parameters } \\
\cline { 2 - 6 } & LW & NS & SW & SD & ED & WPW \\
\hline Stimulate $(S)$ & & & & & \\
$0 \mathrm{~mL} \mathrm{~h}^{-1}$ & $95.21 \mathrm{a}$ & $1.59 \mathrm{a}$ & $176.57 \mathrm{a}$ & $17.95 \mathrm{a}$ & $48.52 \mathrm{a}$ & $512.13 \mathrm{a}$ \\
$250 \mathrm{~mL} \mathrm{~h}^{-1}$ & $93.29 \mathrm{a}$ & $1.421 \mathrm{a}$ & $172.25 \mathrm{a}$ & $18.07 \mathrm{a}$ & $49.31 \mathrm{a}$ & $476.01 \mathrm{a}$ \\
$500 \mathrm{~mL} \mathrm{ha}^{-1}$ & $88.88 \mathrm{a}$ & $1.41 \mathrm{a}$ & $163.65 \mathrm{a}$ & $17.59 \mathrm{a}$ & $48.67 \mathrm{a}$ & $494.44 \mathrm{a}$ \\
\hline Genotypes $(G)$ & & & & & & \\
$\mathrm{P} 3646-\mathrm{HY}$ & $91.60 \mathrm{a}$ & $1.56 \mathrm{a}$ & $169.19 \mathrm{a}$ & $18.62 \mathrm{a}$ & $48.47 \mathrm{a}$ & $493.04 \mathrm{a}$ \\
$30 \mathrm{~A} 37 \mathrm{PW}$ Morgan & $92.23 \mathrm{a}$ & $1.34 \mathrm{~b}$ & $170.15 \mathrm{a}$ & $17.09 \mathrm{~b}$ & $49.33 \mathrm{a}$ & $488.17 \mathrm{a}$ \\
Times $(T)$ & & & & & & \\
$\mathrm{VS}$ & $95.93 \mathrm{a}$ & $1.47 \mathrm{a}$ & $177.69 \mathrm{a}$ & $18.45 \mathrm{a}$ & $50.05 \mathrm{a}$ & $521.94 \mathrm{a}$ \\
$\mathrm{VS}+\mathrm{RS}$ & $86.25 \mathrm{a}$ & $1.36 \mathrm{a}$ & $158.21 \mathrm{a}$ & $17.21 \mathrm{~b}$ & $47.94 \mathrm{a}$ & $448.51 \mathrm{~b}$ \\
$\mathrm{~F}-$ test & & & & & & \\
$\mathrm{S}$ & & & & \\
$\mathrm{G}$ & $0.79^{\mathrm{NS}}$ & $1.12^{\mathrm{NS}}$ & $0.56^{\mathrm{NS}}$ & $0.68^{\mathrm{NS}}$ & $0.26^{\mathrm{NS}}$ & $1.23^{\mathrm{NS}}$ \\
$\mathrm{T}$ & $0.02^{\mathrm{NS}}$ & $5.37^{*}$ & $0.01^{\mathrm{NS}}$ & $16.33^{*}$ & $0.81^{\mathrm{NS}}$ & $0.08^{\mathrm{NS}}$ \\
$\mathrm{S} \times \mathrm{G}$ & $2.56^{\mathrm{NS}}$ & $1.60^{\mathrm{NS}}$ & $1.86^{\mathrm{NS}}$ & $4.37^{*}$ & $2.03^{\mathrm{NS}}$ & $8.44^{*}$ \\
$\mathrm{~S} \times \mathrm{T}$ & $1.43^{\mathrm{NS}}$ & $1.11^{\mathrm{NS}}$ & $1.43^{\mathrm{NS}}$ & $2.76^{\mathrm{NS}}$ & $1.01^{\mathrm{NS}}$ & $2.79^{\mathrm{NS}}$ \\
$\mathrm{G} \times \mathrm{T}$ & $0.79^{*}$ & $1.11^{*}$ & $0.56^{*}$ & $0.68^{*}$ & $0.26^{*}$ & $1.30^{*}$ \\
$\mathrm{~S} \times \mathrm{G} \times \mathrm{T}$ & $1.53^{\mathrm{NS}}$ & $1.11^{\mathrm{NS}}$ & $0.81^{\mathrm{NS}}$ & $2.35^{\mathrm{NS}}$ & $1.14^{\mathrm{NS}}$ & $3.56^{\mathrm{NS}}$ \\
$\mathrm{CV}(\%)$ & $0.79^{*}$ & $1.11^{*}$ & $0.56^{*}$ & $0.68^{*}$ & $0.26^{*}$ & $1.30^{*}$ \\
\hline
\end{tabular}

Note. Means followed by same letters, uppercase in the column and lowercase in the line, are not significantly different by the Tukey's test at $p<0.05$. ** Significant at the level $p<0.01$. ${ }^{*}$ Significant at the level $p<0.05$. ns: not significant.

Significant interaction between levels of Stimulate $\AA$ and times of application on two genotypes of maize (Table 1) and in unfolding this interaction (Table 3), allowed observing that the levels 0 and $250 \mathrm{~mL} \mathrm{ha}^{-1}$ (vegetative stage + reproductive stage), obtained reduction of tassel weight to P3646-HY genotype.

The male inflorescence of maize (tassel) plants should be observed in terms of their characteristics, since this reproductive organ of plants can compete in the production of grains by the translocation of photoassimilates, since there is a larger increment in the grain yield the smaller the dry mass and fresh of the tassel collected in the previous stage or after the anthesis and still in the dry mass after the physiological maturity (Nalin et al., 2013).

Table 3. Split of the interaction of Stimulate ${ }^{\circledR} \times$ Genotypes $\times$ Times with respective tassel weight in $g$ of maize

\begin{tabular}{|c|c|c|c|}
\hline \multicolumn{2}{|c|}{ Treatments } & \multicolumn{2}{|c|}{ Tassel Weight } \\
\hline Stimulate $\AA\left(\mathrm{mL} \mathrm{ha}^{-1}\right)$ & Times & P3646-HY & 30A37PW Morgan \\
\hline 0 & - & $3.36 \mathrm{bA}$ & $4.53 \mathrm{aA}$ \\
\hline 250 & VS & $3.62 \mathrm{aA}$ & $4.70 \mathrm{aA}$ \\
\hline 250 & $\mathrm{VS}+\mathrm{RS}$ & $3.12 \mathrm{bA}$ & $4.39 \mathrm{aA}$ \\
\hline 500 & VS & $3.30 \mathrm{aA}$ & $4.22 \mathrm{aA}$ \\
\hline 500 & $\mathrm{VS}+\mathrm{RS}$ & $3.85 \mathrm{aA}$ & $3.53 \mathrm{aA}$ \\
\hline
\end{tabular}

Note. Means followed by same letters, uppercase in the column and lowercase in the line, are not significantly different by the Tukey's test at $p<0.05$.

Significant interaction between levels of Stimulate $\AA$ and times of application on two maize genotypes (Table 2) and in unfolding this interaction (Table 4), allowed observing that the level $500 \mathrm{~mL} \mathrm{ha}^{-1}$ (vegetative stage + reproductive stage), obtained reduction of leaf weight to 30A37PW Morgan and also in comparison to P3646-HY. 
The effects of biostimulants on soybean treatment provided positive effects in all evaluated parameters: plant height, first pod insertion, number of branches and pods per plant, number of grains per pod, and grain yield, however, in the reproductive stage there was greater efficiency than in the vegetative stage, and the application of both seed and leaf were similar (Bertolin et al., 2010).

Table 4. Split of the interaction of Stimulate ${ }^{\circledR} \times$ Genotypes $\times$ Times with respective leaf weight in $g$ of maize

\begin{tabular}{lllll}
\hline \multicolumn{2}{c}{ Treatments } & & \multicolumn{2}{c}{ Leaf Weight } \\
\cline { 1 - 2 } \cline { 5 - 5 } Stimulate ${ }^{\circledR}\left(\mathrm{mL} \mathrm{ha}^{-1}\right)$ & Times & & P3646-HY & 30A37PW Morgan \\
\hline 0 & - & & $91.18 \mathrm{aA}$ & $99.24 \mathrm{aA}$ \\
250 & VS & & $96.98 \mathrm{aA}$ & $102.01 \mathrm{aA}$ \\
250 & VS e RS & & $84.29 \mathrm{aA}$ & $89.88 \mathrm{aA}$ \\
500 & VS & & $89.25 \mathrm{aA}$ & $95.46 \mathrm{aA}$ \\
500 & VS + RS & & $96.28 \mathrm{aA}$ & $74.53 \mathrm{bB}$ \\
\hline
\end{tabular}

Note. Means followed by same letters, uppercase in the column and lowercase in the line, are not significantly different by the Tukey's test at $p<0.05$.

Significant interaction between levels of Stimulate ${ }^{\circledR}$ and times of application on two genotypes of maize (Table 2) and in unfolding this interaction (Table 5), allowed observing that the levels 250 (vegetative stage) and 500 $\mathrm{mL} \mathrm{ha}{ }^{-1}$ (vegetative stage + reproductive stage), obtained reduction of stem diameter to 30A37PW Morgan genotype. Also, the level $500 \mathrm{~mL} \mathrm{ha}^{-1}$ (vegetative stage + reproductive stage) in comparison to P3646-HY, caused the same effect.

Genotype $\times$ environment interaction is a challenge for cultivar recommendation, however, materials specifically adapted and better management practice, can preventing yield reduction in unfavorable years (Misganaw et al., 2015).

Table 5. Split of the interaction of Stimulate ${ }^{\circledR} \times$ Genotypes $\times$ Times with respective stem diameter in $\mathrm{cm}$ of maize

\begin{tabular}{llllc}
\hline \multicolumn{2}{c}{ Treatments } & & \multicolumn{2}{c}{ Stem Diameter } \\
\cline { 1 - 2 } \cline { 5 - 5 } Stimulate ${ }^{\circledR}\left(\mathrm{mL} \mathrm{ha}^{-1}\right)$ & Times & & P3646-HY & 30A37PW Morgan \\
\hline 0 & - & & $17.91 \mathrm{aA}$ & $17.99 \mathrm{aA}$ \\
250 & VS & & $19.71 \mathrm{aA}$ & $17.72 \mathrm{bA}$ \\
250 & VS + RS & & $17.95 \mathrm{aB}$ & $16.95 \mathrm{aA}$ \\
500 & VS & & $18.96 \mathrm{aA}$ & $17.42 \mathrm{aA}$ \\
500 & VS + RS & & $18.57 \mathrm{aA}$ & $15.39 \mathrm{bB}$ \\
\hline
\end{tabular}

Note. Means followed by same letters, uppercase in the column and lowercase in the line, are not significantly different by the Tukey's test at $p<0.05$.

Significant interaction between levels of Stimulate ${ }^{\circledR}$ and times of application on two maize genotypes (Table 2) and in unfolding this interaction (Table 6), allowed observing that the level $500 \mathrm{~mL} \mathrm{ha}^{-1}$ (vegetative stage + reproductive stage), obtained reduction of whole plant weight to 30A37PW Morgan.

Also, similar at level $500 \mathrm{~mL} \mathrm{ha}^{-1}$ (vegetative stage + reproductive stage) in comparing with the P3646-HY. However, the level of $250 \mathrm{~mL} \mathrm{ha}^{-1}$ (vegetative stage + reproductive stage) reduced this parameter in P3646-HY genotype in relation to 30A37PW Morgan. 
Table 6. Split of the interaction of Stimulate ${ }^{\circledR} \times$ Genotypes $\times$ Times with respective whole plant weight in $\mathrm{cm}$ of maize.

\begin{tabular}{|c|c|c|c|}
\hline \multicolumn{2}{|c|}{ Treatments } & \multicolumn{2}{|c|}{ Whole Plant Weight } \\
\hline 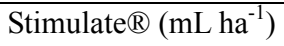 & Times & P3646-HY & 30A37PW Morgan \\
\hline 0 & - & $475.70 \mathrm{aA}$ & $548.56 \mathrm{aA}$ \\
\hline 250 & VS & $553.40 \mathrm{aA}$ & $493.01 \mathrm{aA}$ \\
\hline 250 & $\mathrm{VS}+\mathrm{RS}$ & $413.80 \mathrm{aB}$ & $443.82 \mathrm{aA}$ \\
\hline 500 & VS & $489.68 \mathrm{aA}$ & $551.68 \mathrm{aA}$ \\
\hline 500 & $\mathrm{VS}+\mathrm{RS}$ & $532.65 \mathrm{aA}$ & $403.76 \mathrm{bB}$ \\
\hline
\end{tabular}

Note. Means followed by same letters, uppercase in the column and lowercase in the line, are not significantly different by the Tukey's test at $p<0.05$.

\section{Conclusions}

It is concluded that the number of leaves, number of spikes and stalk diameter were higher to P3646-HY and the tassel weight was higher to 30A37PW Morgan. The application of plant regulator of the doses of 250 and 500 $\mathrm{mL} \mathrm{ha}^{-1}$, divided in the vegetative and reproductive stages, caused a reduction in stem diameter and whole plant weight. The application in single dose in the vegetative stage can increase the amount of bulky, that is, the weight of whole plant, which is the raw material used for the production of silage. The P3646-HY genotype can increase green ear productivity, food sold in natura and much appreciated by brazilian cuisine.

\section{References}

Bertolin, D. C., Sá, M. E., Arf, O., Furlani-Junior, E., Colombo, A. S., \& Carvalho, F. L. B. M. (2010). Increase of the productivity of the soybean crop with the application of biostimulants. Bragantia, 69(2), 339-347. https://doi.org/10.1590/S0006-87052010000200011

Bontempo, A. F., Alves, F. M., Carneiro, G. D. O. P., Machado, L. G., Silva, L. O., \& Aquino, L. A. (2016). Effect of biostimulants and nutrients on seed germination and growth of beans, corn and soybean. Revista Brasileira de Milho e Sorgo, 15(1), 86-93. https://doi.org/10.18512/1980-6477/rbms.v15n1p86-93

Brazil, Ministry of Agriculture. (2011). Normative Instruction No. 46 of October 6.

CONAB (National Supply Company). (2019). Historical series of harvest: Total maize. Retrieved from https://www.conab.gov.br/info-agro/safras/serie-historica-das-safras?start=20

Dourado-Neto D., Dario G. J. A., Barberi A. P. P., \& Martin T. N. (2014). Biostimulant action on agronomic efficiency of corn and common beans. Biosciense Journal, 30(3), 371-379. Retrieved from http://www.seer.ufu.br/index.php/biosciencejournal/article/view/18110

Ertani, A., Schiavon, M., Muscolo, A., \& Nardi, S. (2013). Alfalfa plant-derived biostimulant stimulate short-term growth of salt stressed Zea mays L. plants. Plant and Soil, 364, 145-158. https://doi.org/10.1007/s11104-012-1335-z

Ferreira, D. F. (2011). Sisvar: A computer statistical analysis system. Ciência e Agrotecnologia, 35(1), 1039-1042. https://doi.org/10.1590/S1413-70542011000600001

Galindo, F. S., Nogueira, L. M., Bellote, J. L. M., Gazola, R. N., Alves, C. J., \& Teixeira-Filho, M. C. M. (2015). Agronomic performance of maize in function of the application of biostimulants of algae extract. Tecnologia \& Ciência Agropecuária, 9(1), 13-19. Retrieved from http://revistatca.pb.gov.br/edicoes/ volume-09-2015/volume-9-numero-1-marco-2015/tca9103.pdf

INMET (National Institute of Meteorology). (2014). Retrieved from http://www.inmet.gov.br/portal

Lujan, D. W., Muller, A. L., Sibaldelli, R. N. R., Amaral, H. F., \& Ferreira, R. C. (2015). Influence of technological levels on the grain yield of different commercial maize hybrids in a dystropherric red latosol. Global Science and Technology, 8(1), 79-86. Retrieved from https://rv.ifgoiano.edu.br/periodicos/index.php/ gst/article/view/685/447

Martins, D. C., Borges, I. D., Cruz, J. C., \& Martins-Netto, D. A. (2016). Productivity of maize cultivars submitted to seed treatment with biostimulants liquid fertilizers and Azospirillum sp. Revista Brasileira de Milho e Sorgo, 15(2), 217-228. https://doi.org/10.18512/1980-6477/rbms.v15n2p217-228 
Misganaw, M., Mekbib, F., \& Wakjira, A. (2015). Genotype $\times$ environment interaction on sesame (Sesamum indicum L.) seed yield. African Journal of Agricultural Research, 10(21), 2226-2239. https://doi.org/ 10.5897/AJAR2015.9748.

Nalin, R. S., Moura, R., Guedes, F. L., Goussain, R. C. S., \& Nalin, R. S. (2013). Evaluation of Genetic Variability and Phenotypic Correlations between Tassel Characters and Grain Production of Simple Corn Hybrids (Zea mays L.). 7th Brazilian Congress on Plant Breeding, Uberlândia, MG, Brazil.

Oliveira, F. A., Medeiros, J. F., Cunha, R. C., Souza, M. W. L., \& Lima, L. A. (2016). Use of biostimulants in relieving salt stress in popcorn. Revista Ciência Agronômica, 47, 307-315. https://doi.org/10.5935/ 1806-6690.20160036

Raij, B. V., Andrade, J. C., Cantarella, H., \& Quaggio, J. A. (2001). Chemical analysis for fertility evaluation of tropical soils (1st ed., p. 284).

Santos, V. M., Melo, A. V., Cardoso, D. P., Gonçalves, A. H., Varanda, M. A. F., \& Taubinger, M. (2013). Use of biostimulants on the growth of Zea mays L. plants. Revista Brasileira de Milho e Sorgo, 12(3), $307-318$. Retrieved from https://ainfo.cnptia.embrapa.br/digital/bitstream/item/104573/1/Uso-bioestimulante.pdf

Soil Survey Staff. (2014). Keys to Soil Taxonomy (12th ed.). USDA-Natural Resources Conservation Service, Washington, DC.

Taiz, L., \& Zeiger, E. (2013). Fisiologia vegetal (5th ed., p. 954). São Paulo: Artmed.

Tejada, M., Rodríguez-Morgado, B., Paneque, P., \& Parrado, J. (2018). Effects of foliar fertilization of a biostimulant obtained from chicken feathers on maize yield. European Journal of Agronomy, 96, 54-59.

Trevisan, S., Manoli, A., \& Quaggiotti, S. (2019). A novel biostimulant, belonging to protein hydrolysates, mitigates abiotic stress effects on maize seedlings grown in hydroponics. Agronomy, 9(1), 28. https://doi.org/10.3390/agronomy9010028

Trevisan, S., Manoli, A., Ravazzolo, L., Franceschi, C., \& Quaggiotti, S. (2017). mRNA-Sequencing analysis reveals transcriptional changes in root of maize seedlings treated with two increasing concentrations of a new biostimulant. Journal of Agricultural and Food Chemistry Article, 65(46), 9956-9969. https://doi.org/10.1021/acs.jafc.7b03069

Turco, G. M. S. (2011). Production and physical composition of the corn plant forsilage, cultivated in two fertilization levels, associated with two row spacing and two planting densities (p. 65). Retrieved from

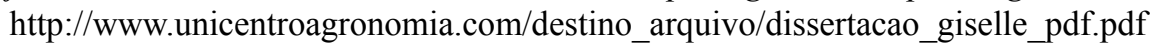

USDA (United States Department of Agriculture). (2019). Retrieved from http://www.usda.gov

\section{Copyrights}

Copyright for this article is retained by the author(s), with first publication rights granted to the journal.

This is an open-access article distributed under the terms and conditions of the Creative Commons Attribution license (http://creativecommons.org/licenses/by/4.0/). 